\title{
ENVIRONMENTAL AWARENESS OF STUDENTS LIVING NEAR SELECTED NATIONAL PARKS IN COUNTRIES OF VISEGRÁD GROUP
}

\author{
Peter Repka ${ }^{1}$, Beata Barabasz-Krasny², Katarzyna Możdżeń², Peter Urban¹, Juraj Švajda ${ }^{1}$ \\ ${ }^{1}$ University of Matej Bel in Banská Bystrica, Slovakia \\ ${ }^{2}$ Institute of Biology Pedagogical University, Poland \\ e-mail: kasiamozdzen@interia.pl
}

Received: 12.04.2017

\begin{abstract}
The aim of this study was to evaluate environmental awareness of young people and effectiveness of education used by national parks. The research occurred in the period from 2012 to 2014. The Vel'ká Fatra National Park (Slovakia), Bohemian Switzerland National Park (Czech Republic), Bieszczady National Park (Poland) and Bükki National Park (Hungary) as parks of countries of the Visegrád Group were analysed. The study was focused on the target group of students of gymnasiums and secondary schools in the regions where national parks are located and outside these regions. In all the analysed countries we used a questionnaire, which was distributed among 1301 students. For each respondent, answers were entered in a spreadsheet and statistically analysed. The following non-parametric statistical tests were used: Kruskal-Wallis, Friedman, Wilcoxon and parametric ANOVA. The best results were noted among students from Poland and the Czech Republic. In other countries of the Visegrád Group therefore it is appropriate to introduce actions aiming at increasing the ecological awareness of students, according to the models of education functioning in national parks and schools in Poland and the Czech Republic. It is also necessary to revise the ways in which national environmental education exists in all studied countries, as well as to strengthen volunteer activities.
\end{abstract}

Key words: environmental awareness, national parks, students of gymnasium and secondary schools, Visegrád Group

\section{Introduction}

In recent decades, human has had significant impact on the natural environment almost all over the world. The natural landscape has been changed almost completely by anthropogenic activities and many other additional factors. However, even under such conditions, a relatively large part of the natural areas were retained where the natural landscape forms survived (Bauer et al., 2009). Nowadays, these areas grapple with the problems - how to survive in the modern world and hold on the values from the past (Brechin et al., 2010; Lockwood, 2010; Mose, 2013; Považan et al., 2014; Dearden \& Bennett, 2015).

There were attempts to implement four main trends in the contemporary environmental protection. The first trend indicated the development of biological aspects of conservation through better understanding of species and their interactions. The second trend showed the development of philosophical aspects of nature conservation which reveal, from a moral point of view, the relationship between human and nature (Bauer et al., 2009; DeFries et al., 2010; Stern, 2010). The third trend suggested reinforcement of environmental legal instruments, public awareness and building an open, democratic community (Brechin et al., 2010). The fourth one included practical protection and care of ecosystems through active procedures used to maintain the state of biotopes (Švajda \& Fenichel, 2011; Mose, 2013; Voll \& Luthe, 2013).

Previous, socially oriented, studies concentrated on the national parks activities, primarily in the area of ecological awareness of inhabitants living in the national park (hereafter also as NP) or its neighbourhood. They present the relationship between society, the environment and protected areas. They also show how the society awareness affects the citizens attitude towards the surrounding nature (e.g., Górecki et al., 2007; Haas et al., 2008; Bauer et al., 2009; DeFries et al., 2010; Dudley et al., 2010; von Ruschkowski \& Mayer, 2011; Neufeld, 2012; Hibszer, 2013; Považan et al., 2014; Bennett \& Dearden, 2014; Stronghill et al., 2015).

National parks, as areas that apply to preserve nature in the most natural state, realise an educational and information function. The role of employees of national parks is to find among others, appropriate methods of education aiming at the acceptance of protected areas by students, residing both in the vicinity of the park and at a distance from it. In protected areas, ecological education should take into account not only the objectives of these areas, but also global and environmental problems. The education should effectively use the natural heritage of protected areas, allowing direct contact with nature. Another challenge is 
to bring people closer to nature through aesthetic education in contact with the beauty of nature. The environmental education conducted by national parks is also a widely recognised instrument for shaping the relationship between the national park and the local community (Hibszer, 2013).

The environmental education should be organised according to the category of participants, for which appropriate methods should be chosen and the language adapted to the level of perception. Among the participants of the educational classes create pro-environmental behaviours, and thus change the way of everyday life (Bizubová \& Nevřelová, 2006; Haas et al., 2008; ŻeberDzikowska, 2012; Możdżeń et al., 2016).

The aim of this study was to evaluate and compare the level of environmental awareness and knowledge of students of gymnasium and secondary schools in the countries of the Visegrád Group (i), in the vicinity or further away from the selected national parks (ii). An additional aim was to propose new potential solutions to improve environmental education in the analysed national parks (iii).

\section{Material and Methods}

STUDYAREA, SAMPLES, INSTRUMENT. Four national parks were chosen for the studies: Vel'ká Fatra National Park $48^{\circ} 55^{\prime} \mathrm{N} 19^{\circ} 04^{\prime} \mathrm{E}$ (Slovakia), Bohemian Switzerland National Park $50^{\circ} 50^{\prime} \mathrm{N} 14^{\circ} 15^{\prime} \mathrm{E}$ (Czech Republic), Bieszczady National Park 49 $17^{\prime} 17^{\prime \prime} \mathrm{N} 22^{\circ} 29^{\prime} 49^{\prime \prime} \mathrm{E}$ (Poland) and Bükki National Park 48 $02^{\prime} 53^{\prime \prime} \mathrm{N} 20^{\circ} 31^{\prime} 41^{\prime \prime} \mathrm{E}$ (Hungary) - Fig. 1.

The study of ecological awareness and knowledge of nature were conducted in the period of 2012-2014 among 1301 students of gymnasium and secondary schools (778 girls and 523 boys) living in the direct vicinity of the selected national parks or at some distance from them. The school selection criterion was the distance to the park, which in the case of schools far from the park exceeded $100 \mathrm{~km}$. The detailed data concerning statistic population, name of the place, the number of respondents answering the studies are shown in Table 1, the percentage of respondents in particular countries and the region of their residence are presented in Table 2.

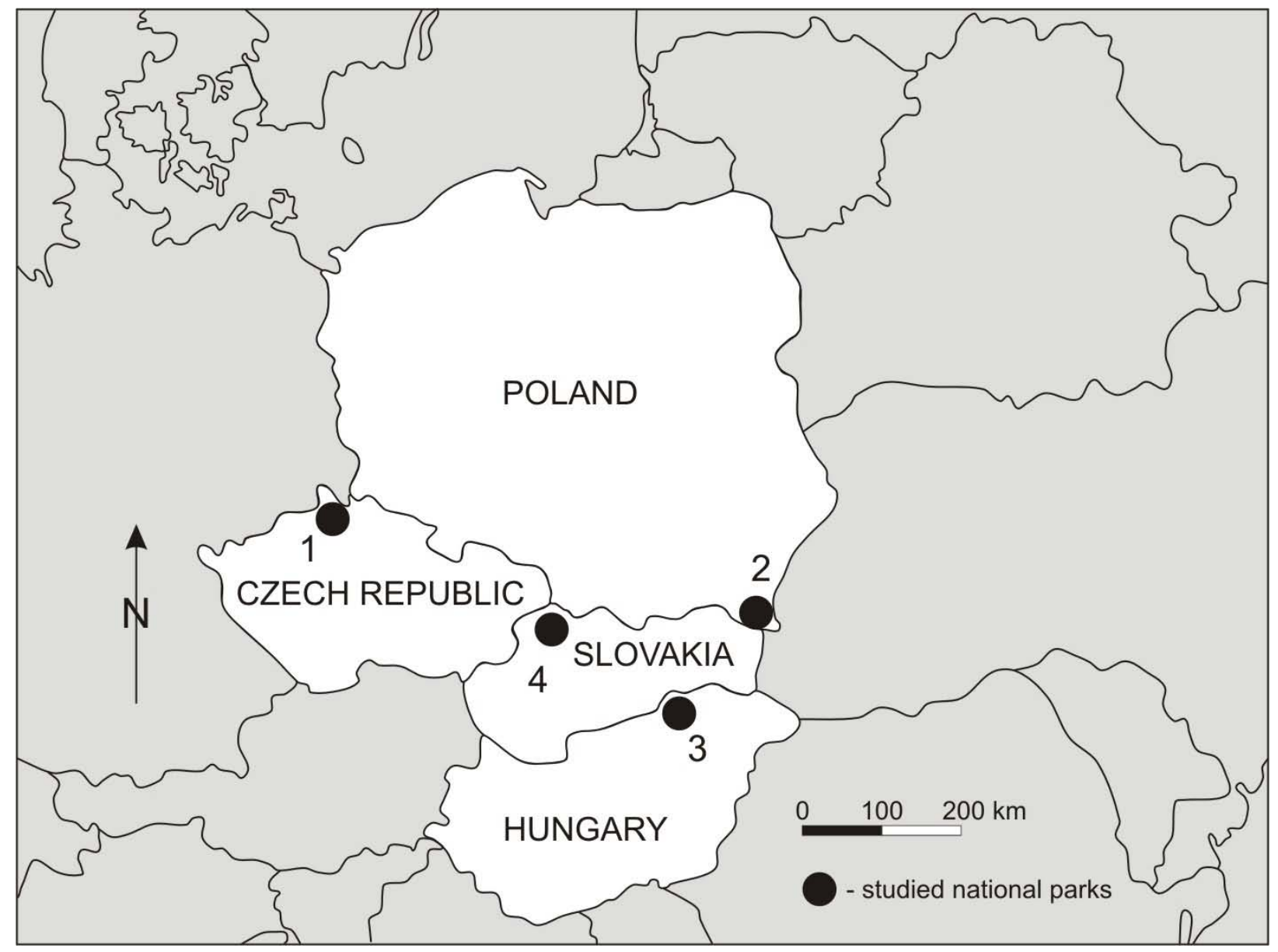

Fig. 1. Localisation of the National Parks selected for the study; 1 - Bohemian Switzerland National Park (Czech Republic), 2 - Bieszczady National Park (Poland), 3 - Bükki National Park (Hungary), 4 - Vel'ká Fatra National Park (Slovakia). 
Table 1. General characteristics of the target groups of the survey

\begin{tabular}{|c|c|c|c|c|}
\hline $\begin{array}{l}\text { National } \\
\text { Park/ } \\
\text { Country }\end{array}$ & $\begin{array}{l}\text { The city in } \\
\text { vicinity of } \\
\text { National Park }\end{array}$ & $\begin{array}{l}\text { The city further } \\
\text { away from the } \\
\text { National Park }\end{array}$ & Name of school & $\begin{array}{l}\text { Number of } \\
\text { respondents }\end{array}$ \\
\hline \multirow{5}{*}{$\begin{array}{l}\text { Bohemian } \\
\text { Switzerland } \\
\text { NP (Czech } \\
\text { Republic) }\end{array}$} & Šluknov & - & $\begin{array}{l}\text { Secondary School of Forestry and } \\
\text { Social Vocational School }\end{array}$ & 127 \\
\hline & - & Nymburk & Middle School of Nymburk & \multirow{4}{*}{133} \\
\hline & - & Kolín & Middle School of Kolín & \\
\hline & - & Čáslav & $\begin{array}{l}\text { Middle School and Secondary } \\
\text { Technical School of Education }\end{array}$ & \\
\hline & - & Kutná Hora & Middle School of Jiří Orten & \\
\hline \multirow{2}{*}{$\begin{array}{r}\text { Bükki NP } \\
\text { (Hungary) }\end{array}$} & Heves & - & $\begin{array}{l}\text { Catholic School of Technology and Economics } \\
\text { of Janos Vak Bottyán and Middle School }\end{array}$ & 99 \\
\hline & - & Debrecen & $\begin{array}{l}\text { Gabor Bethlen Economic Secondary } \\
\text { School and Vocational School }\end{array}$ & 94 \\
\hline \multirow{4}{*}{$\begin{array}{l}\text { Bieszczady } \\
\text { NP (Poland) }\end{array}$} & $\begin{array}{l}\text { Ustrzyki } \\
\text { Dolne }\end{array}$ & - & $\begin{array}{l}\text { Team of High Schools of Józef } \\
\text { Piłsudzki and Lyceum }\end{array}$ & 170 \\
\hline & Krosno & - & $\begin{array}{l}\text { Municipal Team of School No. 4, II } \\
\text { Lyceum of the Constitution of May } 3\end{array}$ & 30 \\
\hline & - & Kraków & II Lyceum of King Jan III Sobieski & 100 \\
\hline & - & Kraków & X Lyceum of the National Education Commission & 96 \\
\hline \multirow{4}{*}{$\begin{array}{c}\text { Velká } \\
\text { Fatra NP } \\
\text { (Slovakia) }\end{array}$} & Žilina & - & Trade School of St. Thomas Aquinas & 171 \\
\hline & Martin & - & Middle School of William Paulína-Tóth & 98 \\
\hline & - & Poprad & Secondary Vocational School "Svit" & 118 \\
\hline & - & Lučenec & Middle School of Božena Slančíkova-Timravy & 65 \\
\hline Total & 6 & 8 & 15 & 1301 \\
\hline
\end{tabular}

Table 2. Division of respondents according to their region of residence

\begin{tabular}{|c|c|c|c|c|c|c|c|c|c|}
\hline \multirow{2}{*}{ Residence } & \multicolumn{2}{|c|}{ Czech Republic } & \multicolumn{2}{|c|}{ Hungary } & \multicolumn{2}{|c|}{ Poland } & \multicolumn{2}{|c|}{ Slovakia } & \multirow{2}{*}{ Total } \\
\hline & village & city & village & city & village & city & village & city & \\
\hline in vicinity of the national park & 36 & 91 & 50 & 49 & 96 & 104 & 130 & 139 & 695 \\
\hline further away from the national park & 60 & 73 & 26 & 68 & 77 & 119 & 65 & 118 & 606 \\
\hline Total & 96 & 164 & 76 & 117 & 173 & 223 & 195 & 257 & 1301 \\
\hline Percentage & 7 & 13 & 6 & 9 & 13 & 17 & 15 & 20 & 100 \\
\hline
\end{tabular}

Explorations concerning the environmental awareness and the level of students education were carried out by a properly designed questionnaire. The questionnaire consisted of 20 questions, which were divided into three areas: students knowledge about the park $-\mathrm{P}$ (8 questions in total), general environmental awareness of students - E (5 questions) and understanding the necessity of nature protection - $\mathrm{O}$ (4 questions in total). The first three questions concerned identification of the data of the survey respondents: gender, age and place of residence. Two survey questions: What sources did you obtain the information about the park from? and Which attractions do you use the most often when visiting the national park? - were not included into any of the three above mentioned groups but they were analysed separately. The survey included 14 closed questions and 4 opened questions in the questionnaire which were prepared in four languages (Czech, Hungarian, Polish and
Slovakian) and in four versions tailored to each of the selected national parks. The questionnaire was distributed in printed forms $(80.1 \%$ of the respondents) or in electronic forms $(19.9 \%$ of the respondents). All respondents were informed about the purpose of the research. The content of the survey and the method of completing the answers were explained to them in details. The survey was anonymous.

DATA ANALYSIS. During the statistical analysis, for each answer the points were awarded: « $+5 »$ points - when the response confirmed understanding of issues related to environmental education, «-5» points - if the received answer did not confirm the kind of respondents awareness, «0» points - if the student did not give any answer. Answers to the open questions which confirmed knowledge of issues relating to environmental education received the maximum of 5 points. The results for each respondent were entered 
into a spreadsheet MS Excel 2007 and analysed statistically by means of the software IBM SPSS Statistics 19. The following non-parametric statistical tests - Mann-Whitney, Kruskal-Wallis, Friedman, Wilcoxon were applied for the analyses, after the Levene'a test of homogeneity of variance. In case of all the tests, the differences where $p \leq 0.05$ were considered significant ones.

Four null hypothesis were tested to obtain the answer to the aims of the research:

$\mathrm{H}_{01}=$ in responses to the questions concerning the following aspects: students knowledge of the park $\mathrm{P}$, general environmental awareness of students $\mathrm{E}$, understanding the necessity of nature protection $\mathrm{O}$, there was no significant difference between the students residing in the direct vicinity of the national park, and at a considerable distance from it,

$\mathrm{H}_{02}=$ in responses to the questions concerning the following aspects: students knowledge of the park P, general environmental awareness of students $\mathrm{E}$, understanding the necessity of nature protection $\mathrm{O}$, there was no significant difference between the students living in cities or villages,

$\mathrm{H}_{03}=$ in responses to the questions concerning the following aspects: students knowledge of the park $\mathrm{P}$, general environmental awareness of students $\mathrm{E}$, understanding the necessity of nature protection $\mathrm{O}$, there was no significant difference between the students from the analysed countries.

$\mathrm{H}_{04}=$ in response to the question: What is in the national park logo?, there was no significant difference between the students from the analysed countries.

The hypotheses $\mathrm{H}_{01}, \mathrm{H}_{02}$, were tested by MannWhitney's test, and the hypothesis $\mathrm{H}_{03}, \mathrm{H}_{04}$ by KruskalWallis test. Based on null hypothesis the alternative hypothesis $\mathrm{H}_{1}, \mathrm{H}_{2}, \mathrm{H}_{3}, \mathrm{H}_{4}$ were formulated.

Additionally, the students level of knowledge, which were expressed in the number of points earned in areas $\mathrm{P}, \mathrm{E}, \mathrm{O}$, was compared for all analysed countries in total and for each country separately.

The attention was focused on the issue of comparing the response obtained to the following questions: Do you know how many national parks are in your country? and What is in the logo of the analysed national park? The results were tested using the Kruskal-Wallis test. In the answers to the following questions: What sources did you obtain the information about the national park from? and Which attractions do you use the most often when visiting the national park? were determined which of the options were usually mentioned by the respondents. Statistical significances were tested using the Friedman test for each country separately.
During testing the significance differences between the answers obtained to the questions: Would you like to engage in environmentally beneficial activities organised by the management of the national park?, Do you agree with the principles of conservation in the national park? and Will closing the national park as an institution have a negative impact on the region? separately for each country the Wilcoxon test was used. Additionally, the percentage of answers to the questions was given.

\section{Results and Discussion}

Based on the results of the tests, the hypothesis $\mathrm{H}_{01}=$ in answers to the questions concerning the areas P (Mann-Whitney test: $Z=-1.303 ; p=0.193>0.05$ $\left.\rightarrow \mathrm{H}_{01}\right), \mathrm{E}\left(\mathrm{Z}=-0.764 ; \mathrm{p}=0.445>0.05 \rightarrow \mathrm{H}_{01}\right)$ there were no significant differences between the students living in the direct vicinity of the national park and at considerable distance from it. In case of the area $\mathrm{O}$ $\left(Z=-2.914 ; p=0.004<0.05 \rightarrow H_{1}\right)$ the hypothesis was rejected. More answers, which testifying to understanding the nature protection, were obtained by students who are living in the neighbourhood of the national park. It can be assumed that the distance between the school and the national park, which play the role of a local environmental education centre, had some influence in terms of understanding the necessity of nature protection. This impact was not big enough in case of the other analysed areas. There is an obvious need for closer co-operation between national parks and schools, especially that, e.g. the order answers given by the students to the question: What sources did you obtain the information about the national park from? was as follows: the school, the Internet, home media (TV, radio), publications (Friedman test: $\chi^{2}=722.559$, $\mathrm{df}=4, \mathrm{p}=0.000<0.05)$. It is also necessary to pay more attention to the updating of the parks websites. They should be more attractive to young people and other target groups. These intentions should be implemented through effective promotion of information about the national parks and also their objectives and plans (e.g., tours, seminars, lectures and presentations of park management institutions) (Haas et al., 2008; Urban \& Bitušík, 2015).

The order of answers to the question: Which attractions do you use the most often when visiting the national park? was as follows: hiking trails, others (monuments, ski resorts), bathing places (Friedman test: $\chi^{2}=1096.653, \mathrm{df}=4, \mathrm{p}=0.000<0.05$ ). More such type answers were provided by students from the Czech Republic and Poland than from Hungary and Slovakia. It should be recommended, to focus 
more attention on diversifying the offer of tourism and recreation in the parks (Fig. 2). Necessary are organised seasonal information points relating to nature-tourist and to update information for visitors on the national park website, e.g. weather information, trails availability, occurrence of didactic nature trails, transport access to the main tourist routes and others. These proposals concern in particular the Vel'ká Fatra National Park, which is confirmed by the fact that visitors come to the park mostly for one or two days (Považan et al., 2014). It is necessary to create new opportunities of sport, cultural, tourist and educational activities for visitors but without nature damage (Boyd \& Butler, 2009; Eagles, 2009; Švajda, 2009; Karanth \& DeFries, 2010; Monz et al., 2010; McCool et al., 2012; Ardoin et al., 2015; Kolasińska et al., 2015).

The hypothesis $\mathrm{H}_{02}=$ in answers to the questions in the areas of $\mathrm{P}, \mathrm{E}, \mathrm{O} \mathrm{O}$ - there were no significant differences between the students living in cities or villages situated in the vicinity or further away from the national parks in the analysed countries, was not rejected (Mann-Whitney test: in the aspect $P$ value $\mathrm{Z}=-0.581 ; \mathrm{p}=0.561>0.05 \rightarrow \mathrm{H}_{02}$, aspect $\mathrm{E}$ value $\mathrm{Z}=-0.761 ; \mathrm{p}=0.447>0.05 \rightarrow \mathrm{H}_{02}$, aspect $\mathrm{O}$ value $\mathrm{Z}=-0.052 ; \mathrm{p}=0.958>0.05 \rightarrow \mathrm{H}_{02}$ ). It results from the fact that the disparities in access to information in case of students from cities and villages were almost entirely eliminated. Probably students living in rural areas, who commute to schools located in cities, benefit from better access to the Internet, and their school and Internet set the primary source of information, as it was confirmed by this study.

The hypothesis $\mathrm{H}_{03}=$ in answers to the questions concerning the areas $\mathrm{P}$ (Kruskal-Wallis test: $\left.\chi^{2}=201.461 ; \mathrm{df}=3 ; \mathrm{p}=0.000<0.05 \rightarrow \mathrm{H}_{3}\right), \mathrm{E}$ $\left(\chi^{2}=22.461 ;\right.$ df $\left.=3 ; \mathrm{p}=0.000<0.05 \rightarrow \mathrm{H}_{3}\right) \mathrm{O}$ $\left(\chi^{2}=225.201 ; \mathrm{df}=3 ; \mathrm{p}=0.000<0.05 \rightarrow \mathrm{H}_{3}\right)$, there was no significant difference between students from different countries, was rejected. For all analysed countries, the best total result occurred in the answers given by the students to the questions concerning the area $\mathrm{E}(50 \%$ of respondents achieved not more than 12.5 points), and the poorest one in the area $\mathrm{O}(50 \%$ of respondents achieved not more than 7.5 points) (Fig. 3 ). In comparison with other areas, in the area $E$ the greatest dispersion of results was also observed. There were respondents who had extremely poor knowledge concerning the problem. Some of them achieved a negative result. Comparing the level of knowledge expressed as the number of points obtained in the studies for each country separately showed that in area P students from the Czech Republic achieved the best results $(50 \%$ of respondents achieved not more than 12.5 points), and the poorest one in students from Hungary ( $50 \%$ of respondents achieved not more than 7.0 points). In the area $\mathrm{E}$, the best results were achieved by Polish students $(50 \%$ of respondents achieved not more than 14.0 points), while the poorest one were observed in Hungary $(50 \%$ of respondents achieved not more than 11.0 points). The situation was similar in case of the area $\mathrm{O}$ - the best results were obtained by the students from Poland $(50 \%$ of respondents achieved not more than 11.0 points), and the poorest ones in Hungary (50\% of respondents achieved not more than 3.0 points) (Fig. 4a-d). Generally, the poorest results were observed among Hungarian students and the best ones among Polish students. This situation was probably the outcome of the fact that environmental education is in the curriculum in gymnasium and secondary schools in Poland. There is a clearly defined ministerial core curriculum that students must acquire. During this subject, teachers also focus on information about the region of residence what affects the overall level of students environmental awareness. Additionally, for students were organised weekly nature trips named «green schools». In the Czech Republic, environmental education at schools is carried out by environmental education coordinators who help teachers to implement environmental education for each subject. In this model, the emphasis is put on professionalism of the work of coordinators. Coordinators are trained in environmental education centres. In Poland and the Czech Republic, there is also a very close cooperation in the field of environmental education between the national parks and schools (Švecová, 2008). In Hungary is the subject of "Get to know nature», where students learn how to build positive relationships with nature. But this subject is not compulsory in the curriculum, but only recommended. It depends on the teacher how it will be realised. It is also recommended to organise weekly nature trips, so-called «forest school». However, in specialised subjects, such as biology and ecology, not much time is devoted to environmental education. A similar situation occurs in Slovakia where environmental education is a part of the curriculum, but the extent to which it is implemented depends on the teacher. Hence, it would be advisable to apply a system of environmental coordinators, like in the Czech model, in Slovakian and Hungarian schools. It will help teachers to create core curricula of individual subjects, which will enable to increase the environmental awareness of students. This will also allow tightening cooperation in this area between schools and national parks (Stern et al., 2012). 


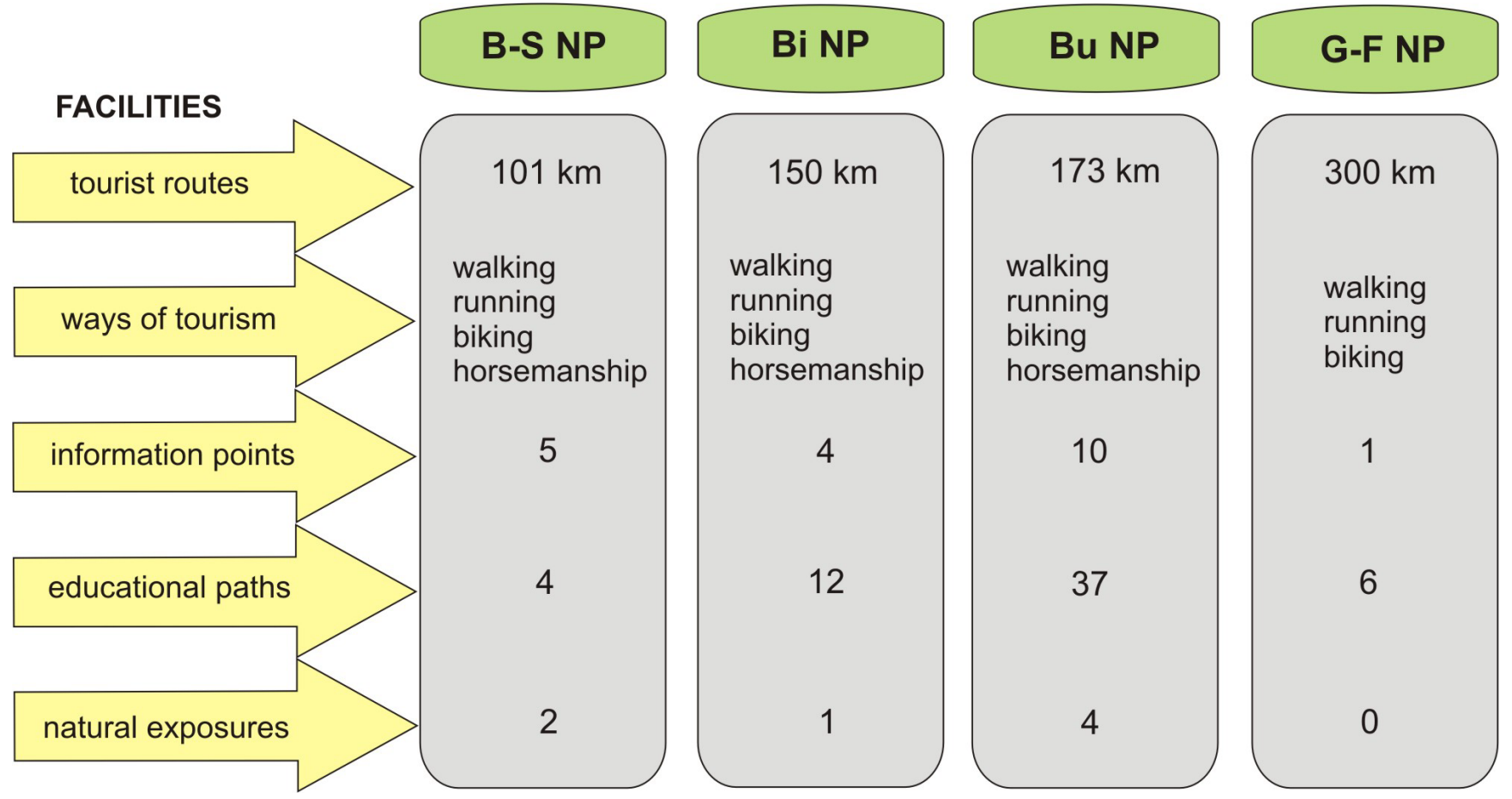

Fig. 2. Comparison of facilities that can be used in environmental education in the analysed national parks of the Visegrád Group: B-S NP - Bohemian Switzerland National Park, Bi NP - Bieszczady National Park, Bu NP - Bükki National Park, G-F NP - Vel'ká Fatra National Park.

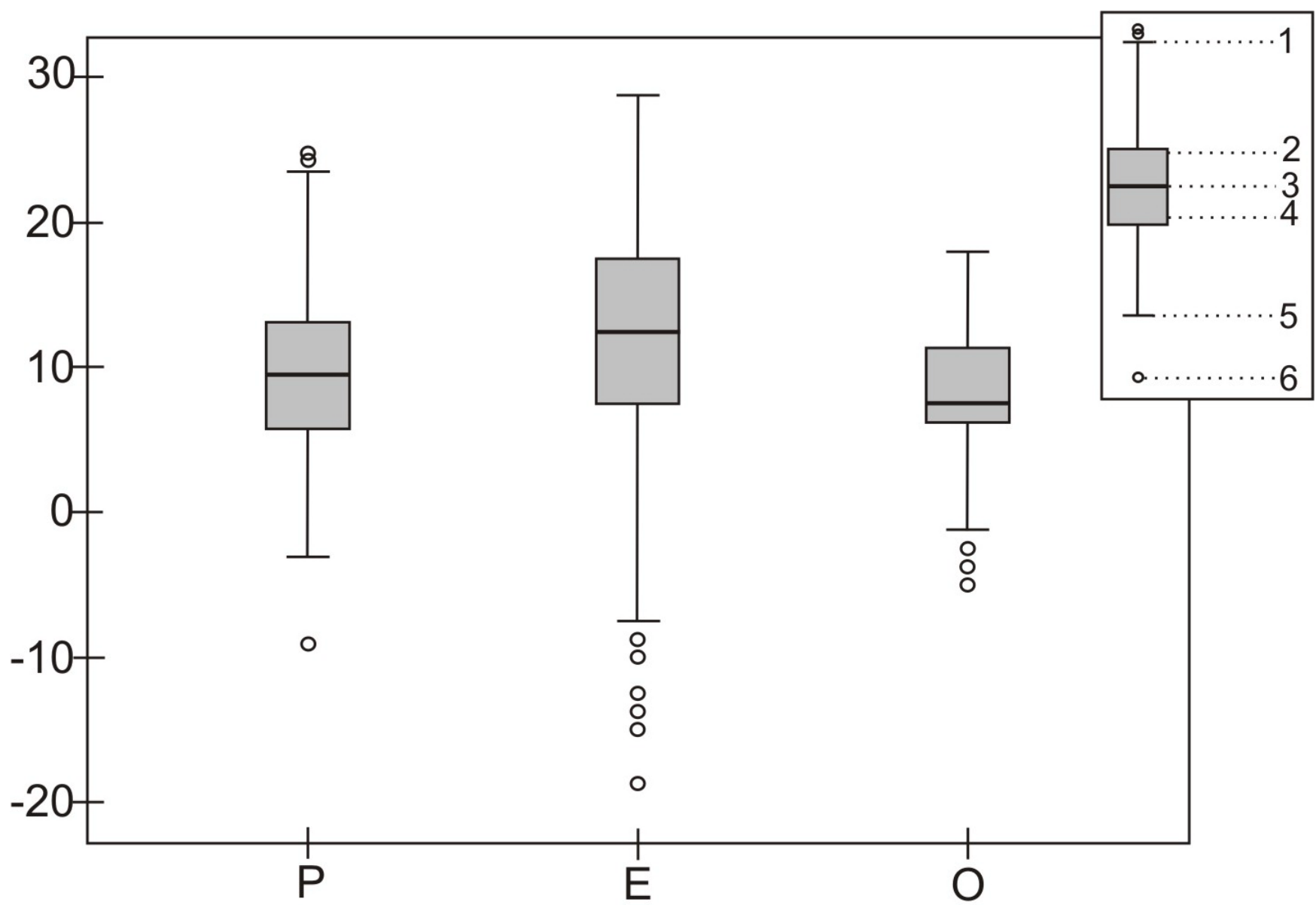

Fig. 3. Comparison of the level of students knowledge together for all the countries of the Visegrád Group, expressed as the amount of points obtained in surveys into areas: knowledge about the park $-\mathrm{P}$ (median: 9.5), general environmental awareness of students - E (median: 12.5), and understanding the necessity of nature protection - $\mathrm{O}$ (median: 7.5 ); 1 - maximum, 2 - upper quartile, 3 - median, 4 - lower quartile, 5 - minimum, 6 - extremum. 

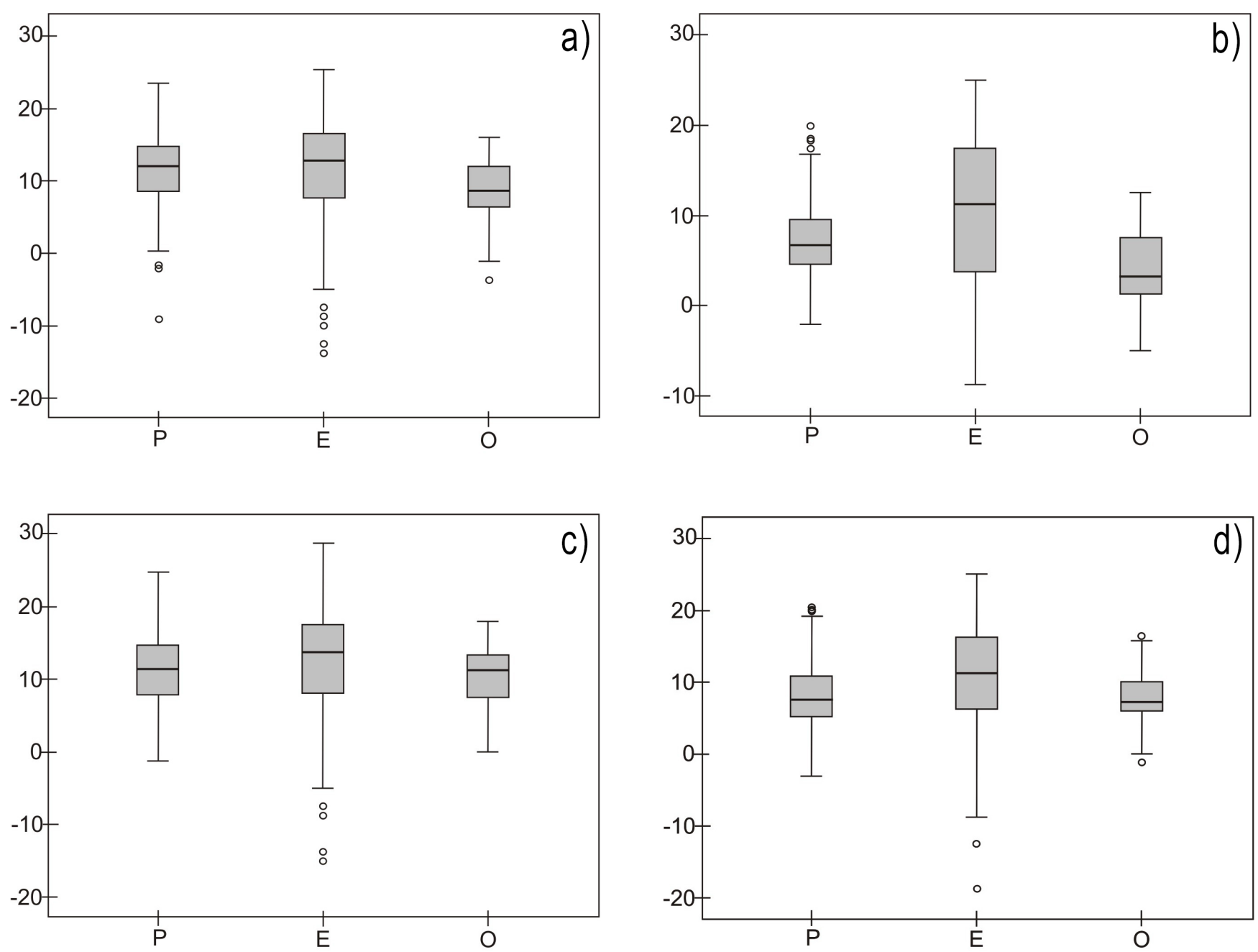

Fig. 4. Comparison of the level of students knowledge: a) in Czech Republic (median: $P=12.0, E=12.5, O=8.5$ ), b) in Hungary (median: $\mathrm{P}=7.0, \mathrm{E}=11.0, \mathrm{O}=3.0$ ), $\mathrm{c}$ ) in Poland (median: $\mathrm{P}=11.5, \mathrm{E}=14.0, \mathrm{O}=11.0$ ), $\mathrm{d}$ ) in Slovakia (median: $\mathrm{P}=8.0$, $\mathrm{E}=11.3, \mathrm{O}=7.0$ ), expressed as the amount of points obtained in surveys into areas: knowledge about the park $-\mathrm{P}$, general environmental awareness of students - E, and understanding the necessity of nature protection - O; explanations see Fig. 3.

The hypothesis $\mathrm{H}_{04}$ = in answers to the question: What is in the logo of the analysed national park?, was a significant difference between students from the analysed countries, was also rejected (KruskalWallis test: $\chi^{2}=320.197 ; \mathrm{df}=3 ; \mathrm{p}=0.000<0.05 \rightarrow$ $\left.\mathrm{H}_{4}\right)$. The highest number of students who knew the logo of the selected park were in the Czech Republic, the lowest one were in Slovakia. Also differences in answers to the questions Do you know how many national parks are in your country? and What is in the logo of the analysed national park? were statistically significant (Kruskal-Wallis test: for the first question the value was $\chi^{2}=315.856, \mathrm{df}=3, \mathrm{p}=0.000<0.05$, for the second one it was $\chi^{2}=320.197$, df $=3$, $\mathrm{p}=0.000<0.05)$. In case of the first question, the highest number of answers confirming the knowledge of the subject were from students of Poland, the Czech Republic, Slovakia, Hungary, in case of the second one - from the Czech Republic, Poland, Hungary and Slovakia. Unsatisfactory answers given by the Slovak respondents in case of the knowledge of the national park logo can be explained by the fact, that the Management of the Vel'ká Fatra National Park is not perceived as an institution in such form as the managements of other foreign national parks. Such an unfavourable effect is partly caused by the lack of a website and a relatively small number of appearances of the board of the park in the local and national media. Comparison of national parks websites from Slovakia, Poland and the Czech Republic showed that the websites of national parks from Slovakia were evaluated the lowest (Repiský \& Švajda, 2012). Probably this factor had a significant impact for recognition of the Vel'ká Fatra National Park logo by respondents from the analysed Slovakian students group. It also confirms the fact, that the Internet is one of the most frequently mentioned sources of information about parks used by students.

When testing differences between the answers given to the questions: Would you like to engage in environmentally beneficial activities organised 
by the management of the national park?, Do you agree with the principles of conservation in the national park? and Will closing the national park as an institution have a negative impact on the region?, there were statistically significant differences between the answers to these questions in the studied countries (Wilcoxon test: Czech Republic - between the first and the second question $-Z=-7.160^{\mathrm{a}}, \mathrm{p}=0.000<0.05$, between the second and the third one $-Z=-2.500^{\mathrm{b}}$, $\mathrm{p}=0.012<0.05$; Hungary - between the first and the second question $-Z=-3.780^{\mathrm{a}}, \mathrm{p}=0.000<0.05$, between the second and third one $-Z=-3.130^{b}$, $\mathrm{p}=0.002<0.05$; Poland - between the first and the second question $-Z=-10.818^{\mathrm{a}}, \mathrm{p}=0.000<0.05$, between the second and the third one $-Z=-2.000^{b}$, $\mathrm{p}=0.046<0.05$; Slovakia - between the first and the second question $-Z=-1.103^{a}, p=0.000<0.05$, between the second and the third one $-\mathrm{Z}=-3.545^{\mathrm{b}}$, $p=0.000<0.05)$. Most answers, which are indicators of knowledge of the environmentallyfriendly activities organised by the national park, were given by students from Hungary and the Czech Republic, and least one from Poland and Slovakia (a total of $32.40 \%$ of the respondents wanted to participate in this activity, $29.30 \%$ did not want to involved, and $38.30 \%$ of the respondents did not reply to this issue). Most students, who agreed with the principles of protection in national parks, were from Slovakia and the fewest from Hungary (in total, there were $90.10 \%$ «yes», $2.60 \%$ «no», and $7.30 \%$ «I do not know» answers of the respondents). In all countries, students thought that liquidation of the national park would harm the region, but in Hungary, compared to the other countries, there were less students of this view $85.20 \%$. On the contrary, most such answers were given by the students from Poland $-94.50 \%$.

It is important for the management of the national parks to focus on the target group of students who were responded «I do not know» to the above questions. By means of appropriate forms (promotional materials, lectures, discussions with experts), it should be explained clearly to the group why it is essential to engage in such type of activities and what are intentions and functions of national parks (Powell et al., 2011; Stern et al., 2012; Weiland \& Morrison, 2013; Stern et al., 2014). In this way, the number of «undecided» students could be reduced and lead to a closer co-operation between the school and the national park. Greater participation in the work of voluntary brigades might result in general increase of public interest in voluntary assistance provided for the national parks. For example in 2014, 18 brigades of volunteers, which consisted of 458 people, worked in the Bohemian Switzerland National Park. In contrast, the Bükki National Park Brigades are called in only on a given day. This park has a very well developed co-operation with social organisations, which is not based on financial aid, but on attracting volunteers to the earlier announced work carried out in a voluntary form. In the Vel'ká Fatra National Park, there is only one active voluntary brigade a year and the number of people involved in the activity is different. In 2014, 35 people signed up for voluntary work in the Bieszczady National Park. However, voluntary work has some restrictions there. It is not a one-off event as volunteers involved to the work in the park spend a few days there (costs of travel, food and accommodation are financed by the park). The volunteers must be of legal age, fit, have a basic knowledge of the park and a good sense of directions in the area. The situation is more favourable in the Czech Republic and Hungary because the conditions of volunteering there are not as strict as in Poland. In those countries, the seasonal activities which enable to engage people (cleaning natural and cultural areas, garbage collection, transfer of amphibians, etc.), can be promoted throughout the year. The offer of this type is addressed to the general public, not only to gymnasium and secondary schools students or adults (Górecki et al., 2007; České Švýcarsko NP, 2015).

\section{Conclusions}

The studies confirmed differences in the environmental awareness of students from gymnasium and secondary schools from the countries belonging to the Visegrád Group (i) who live in the vicinity or further away from the selected national parks, especially in case of understanding the needs of nature conservation (ii). The fact is associated with activities of national parks which are institutions functioning for the whole society. Those activities should be expanded as in case of the analysed student groups the knowledge about parks and general ecological awareness seems to be insufficient. In that area, it might be recommended to focus on strengthening cooperation between the national parks and schools. Students from Poland and the Czech Republic achieved the best overall results in the carried out studies. It seems to be appropriate to introduce measures increasing environmental awareness of students, similar to 
the education models functioning in national parks and schools in those countries. It is necessary to revise the ways of environmental education in the individual countries as well as to strengthen volunteer activities (iii).

\section{References}

Ardoin N.M., Wheaton M., Bowers A.W., Hunt C.A., Durham W.H. 2015. Nature-based tourism's impact on environmental knowledge, attitudes, and behavior: a review and analysis of the literature and potential future research. Journal of Sustainable Tourism 23(6): 838-858.

Bauer N., Wallner A., Hunziker M. 2009. The change of European landscapes: Human-nature relationships, public attitudes towards rewilding, and the implications for landscape management. Journal of Environmental Management 90: 2910-2920.

Bennett N.J., Dearden P. 2014. Why local people do not support conservation: Community perceptions of marine protected area livelihood impacts, governance and management in Thailand. Marine Policy 44: 107-116.

Bizubová M., Nevřelová M. 2006. Význam náučných chodníkov v krajine a jej ochrane. Acta Environmentalica Universitatis Comenianae (Bratislava) 14 (2): 5-10.

Boyd S., Butler R. 2009. Tourism and the Canadian National Park System: Protection, Use and Balance. In: W. Frost, H. Hall (eds.): Tourism and National Parks. London: Routledge. P. 102-113.

Brechin S.R., Murray G., Mogelgaard K. 2010. Conceptual and practical issues in defining protected area success: The political, social, and ecological in an organized world. Journal of Sustainable Forestry 29(2-4): 362-389.

České Švýcarsko N.P. 2015. Administration of Czech Switzerland National Park. In: Yearbook 2014. Year report. Krásna Lípa (VA). The manuscript is available in the library of the Czech Switzerland National Park.

Dearden P., Bennett N.J. 2015. Parks and protected areas. In: Resource and Environmental Management in Canada. $5^{\text {th }}$ edition. Chapter 13. Oxford: Oxford University Press. P. 318-344.

DeFries R., Karanth K.K., Pareeth S. 2010. Interactions between protected areas and their surroundings in human-dominated tropical landscapes. Biological Conservation 143(12): 2870-2880.

Dudley N., Stolton S., Belokurov A., Krueger L., Lopoukhine N., MacKinnon K., Sandwith T., Sekhran N. (eds.). 2010. Natural Solutions: Protected areas helping people cope with climate change. Gland, Switzerland; Washington DC and New York, USA: IUCN-WCPA, TNC, UNDP, WCS, The World Bank and WWF. 130 p.

Eagles P.F.J. 2009. Governance of recreation and tourism partnerships in parks and protected areas. Journal of Sustainable Tourism 17(2): 231-248.

Górecki A., Nieszporek K., Ostruszka A., Skolarczyk L., Wójcik M. 2007. Świadomość ekologiczna młodzieży zamieszkującej okolice wybranych parków narodowych. Roczniki Bieszczadzkie 5: 283-302.
Haas M., Ondrová E., Švajda J. 2008. Environmental education. Žilina: Institute of High Mountain Biology; University of Žilina Press. 132 p.

Hibszer A. 2013. Parki Narodowe $w$ świadomości $i$ działaniach społeczności lokalnych. Katowice: University of Silesia. 358 p.

Karanth K.K., DeFries R. 2010. Nature-based tourism in Indian protected areas: New challenges for park management. Conservation Letters 4: 137-149.

Kolasicska A., Adamski P., Ciapaia S., Švajda J., Witkowski Z. 2015. Trail management, off-trail walking and visitor impact in the Pieniny Mts National Park (Polish Carpathians). Eco-mont. Journal on Protected Mountain Areas Research Management 7(1): 26-36.

Lockwood M. 2010. Good governance for terrestrial protected areas: a framework, principles and performance outcomes. Journal of Environmental Management 91: 754-766.

McCool S., Hsu Y.C., Rocha S.B., Sopórsdóttir A.D., Gardner A.L., Freimud W. 2012. Building the capability to manage tourism as support for the Aichi Target. Parks, the International Journal for Protected area Managers 18(2): 92-106.

Monz C.A., Cole D.N., Leung Y.F., Marion J.L. 2010. Sustaining Visitor Use in Protected Areas: Future Opportunities in Recreation Ecology Research Based on the USA Experience. Environmental Management 45(3): 551-562.

Mose I. 2013. Societal research perspectives on protected areas in Europe: priorities for future research. In: 5 th Symposium for Research in Protected Areas (10-12 June, 2013). Mittersil. P. 527.

Możdżeń K., Możdżeń E., Barabasz-Krasny B., Sołtys-Lelek A. 2016. Świadomość ekologiczna młodzieży ponadgimnazjalnej. In: D. Żołnierczuk-Kieliszek, M. Janiszewska (eds.): Zdrowie, psychologia, społeczeństwo - przeglad wybranych zagadnień. Tygiel, Lublin, Polska. P. 199-215.

Neufeld D. 2012. Indigenous peoples and protected heritage areas: acknowledging cultural pluralism. In: K.S. Hanna, D.A. Clark, D.S. Slocombe (eds.): Transforming parks and protected areas: policy and governance in a changing world. New York: Routledge. P. 181-199.

Powell R.B., Stern M.J., Krohn B.D., Ardoin N. 2011. Development and validation of scales to measure environmental responsibility, character development, and attitudes toward school. Environmental Education Research 17(1): 91-111.

Považan R., Getzner M., Švajda J. 2014. Value of ecosystem services in Mountain National Parks. Case study of Vel'ká Fatra National Park (Slovakia). Polish Journal of Environmental Studies 23(5): 1699-1710.

Repiský L', Švajda J. 2012. Hodnotenie webov národných parkov Slovenska. In: Enviro-i-fórum 2012: zbornik príspevkov konferencie, odborné fórum o environmentálnej informatike. Slovenská agentúra životného prostredia Zvolen. P. 75-78.

Stern M.J. 2010. Payoffs versus process: expanding the paradigm for park/people studies beyond economic rationality. Journal of Sustainable Forestry 29(2-4): 174-201. 
Stern M.J., Wright M.E., Powell R.B. 2012. Motivating participation in national park service curriculum-based education programs. Visitor Studies 15(1): 28-47.

Stern M.J., Powell R.B., Hill D. 2014. Environmental education program evaluation in the new millennium: what do we measure and what have we learned? Environmental Education Research 20(5): 581-611.

Stronghill J., Rutherford M.B., Haider W. 2015. Conservancies in Coastal British Columbia: A New Approach to Protected Areas in the Traditional Territories of First Nations. Conservation and Society 13: 39-50.

Švajda J. 2009. Contribution for Improvement of Visitor Monitoring in the Tatra National Park. Eco-mont. Journal on Protected Mountain Areas Research Management 1(2): 13-18.

Švajda J., Fenichel E.P. 2011. Evaluation of Integrated Protected Area Management in Slovakian National Parks. Polish Journal of Environmental Studies. 20(4): 1053-1060.

Švecová M. 2008. Skúsenosti z krajín EÚ. In: M. Švecová, K. Sásiková (eds.): Výchova $k$ udržatel’nému rozvoju v podmienkach škôl a jej manažment. Banská Bystrica: Fakulta prírodných vied UMB. P. 131-142.

Urban P., Bitušík P. 2015. Výučba ochrany prírody na Katedre biológie a ekológie FPV UMB v Banskej Bystrici a jej úskalia. Quaestiones rerum naturalium 2: 89-100.

Weiland I.S., Morrison J.A. 2013. The Integration of Environmental Education into Two Elementary Preservice Science Methods Courses: A Content-Based and a Method-Based Approach. Journal of Science Teacher Education 24(6): 1023-1047.

Voll F., Luthe T. 2013. A systemic perspective on sustainable governance of protected areas. Eco-mont. Journal on Protected Mountain Areas Research Management 6(1): 15-22.

von Ruschkowski E., Mayer M. 2011. From Conflict to Partnership? Interactions between Protected Areas, Local Communities and Operators of Tourism Enterprises in Two German National Park Regions. Journal of Tourism and Leisure Studies 17(2): 147-181.

Żeber-Dzikowska I. 2012. Projekty edukacyjne - propagowanie ochrony przyrody i turystyki. Edukacja Biologiczna i Środowiskowa 4(44): 123-131.

\title{
ЭКОЛОГИЧЕСКАЯ ОСВЕДОМЛЕННОСТЬ СТУДЕНТОВ, ЖИВУЩИХ БЛИЗ НЕКОТОРЫХ НАЦИОНАЛЬНЫХ ПАРКОВ В СТРАНАХ ВЫШЕГРАДСКОЙ ГРУППЫ
}

\author{
П. Репка ${ }^{1}$, Б. Барабаш-Красны ${ }^{2}$, К. Можджен ${ }^{2}$, П. Урбан ${ }^{1}$, Ю. Швайда ${ }^{1}$ \\ ${ }^{1}$ Университет Матей Бела в Банксе Быстрице, Словакия \\ ${ }^{2}$ Институт биологии педагогического университета, Польша \\ e-mail:kasiamozdzen@interia.pl
}

\begin{abstract}
Целью настоящего исследования было оценить экологическую осведомленность молодых людей и эффективность образования, проводимого национальными парками. Исследование проводилось с 2012 по 2014 гг. Были выбраны следующие национальные парки стран Вышеградской группы: национальный парк Велька Фатра (Словакия), национальный парк Чешская Швейцария (Чешская Республика), национальный парк Бещады (Польша) и национальный парк Бьюкки (Венгрия). Исследование было направлено на целевую группу учащихся гимназий и школ в регионах, где выбранные национальные парки находятся и за пределами этих территорий. Во всех исследованных странах нами был использован метод анкетирования, примененный на 1301 учащемся. Ответы каждого опрошенного были внесены в анкету и статистически проанализированы. Были использованы следующие статистические тесты: Крускал-Уолиса, Фридмана, Уилкоксона и Mann-Whitney. Наилучшие результаты были отмечены среди учащихся Польши и Чешской Республики. Таким образом, в остальных странах Вышеградской группы уместно проведение мероприятий по повышению экологической осведомленности учащихся в соответствии с функционирующими моделями проведения образовательной деятельности в национальных парках и школах Польши и Чешской Республики. Также необходима ревизия методов, которыми осуществляется экологическое образование во всех странах, а также усиление волонтерской деятельности.
\end{abstract}

Ключевые слова: Вышеградская группа, национальные парки, студенты гимназий и школ, экологическая осведомленность 